\title{
Effect of Crop Sequence, Compost and Plant Residues on Maize Yield Production, Sandy Soil Fertility and Reduce N-Mineral Fertilizer
}

\author{
"Mona M. Abou El-Nour ${ }^{1}$ and Soad Y. Serry ${ }^{2}$ \\ ${ }^{1}$ Botany Department, Women's College, Ain Shams University, Cairo, Egypt. \\ *Monamn2003@yahoo.com \\ ${ }^{2}$ Soils, Water and Env. Res. Inst.; Agric. Res. Center, Giza, Egypt
}

Received on: 9/8/2018

Accepted for publication on: $28 / 8 / 2018$

Abstract

Continuous population growth gives rise to food problems in developing countries, which requires enhancement in quantity and quality of agricultural products as well as reduce fertilizer use. Therefore a cropping system study was carried out to establish good agricultural practices that decrease soil degradation and building up fertility of desert soils in Egypt. Accordingly, two rotation cycles were established to investigate the effect of inclusion legume crop (pea) in the rotation compared to heavy feeder crop (potato), on yield and its components of the subsequent crop (maize) as well as soil organic matter level and microbial activity. Addition of biofertilizers, organic fertilizer and different levels of inorganic $\mathrm{N}$ were also applied to study their integrated effect on improving nutrients availability for maize crop and the investigated sandy soil as well. Results have been shown that the co-application of organic and inorganic fertilizers in the pea/corn rotation improved yield responses and NPK accumulation in maize crop relative to potato/corn rotation. Since the quality of soil is strongly related to several interactions between chemical and biological factors, significant variation was detected in chemical properties (organic $\mathrm{C}$, total $\mathrm{N}$ and available $\mathrm{P}$ and $\mathrm{K}$ ) and biological properties (total microbial count, $\mathrm{CO}_{2}$ evolution and dehydrogenases activity) for soil of organically treated plots compared to inorganically treated one under different sequence practices. It was concluded that balanced fertilization using both bio- and organic as well as chemical fertilizers under pea/maize sequence was reported to improve crop productivity and reduce inorganic $\mathrm{N}$ fertilizer requirement.

Keywords: Legume crop rotation, Compost, Biofertilizer, Desert soil.

\section{Introduction}

Requirement for food is rising as the human population increases, without good concern through modification of the present practices or the discovery of new options, food production will continue to decrease per capita and per unit area. Unbalanced use of chemical fertilizers reduces soil fertility and quality of crops (Malakooti and Gheybi, 2003). Enhancement of current agriculture production system is required to correct this bad situation. On the other hand, the use of organic fertilizers (e.g., animal manure, crop residues and green manure) as alternative source of chemicals holds promise. Nitrogen is the most yield-limiting nutrient in crop production worldwide and mainly the most important factor needed for improving crop productivity and profitability (Guo et al., 2016 and Amanullah et al., 2016). Rotation is one of the valuable tools for nutrient recycling, which accelerate the 
microbial activity of the soil, permits better nutrient accessibility and higher crop yield (Pokhrel and Pokhrel 2013). Preissel et al. (2015) evaluated the net input of fixed $\mathrm{N}$ in cropping systems and noticed that legume-fixed $\mathrm{N}$ might improve the productivity of the subsequent crops, and increase farm- economic values comparable to cereal rotations. Xing et al. (2017) illustrated that including grain legumes in cereal-based crop rotations was more profitable than non-legume crop rotations. They studied the effect of including Pisum sativum and Lupinus angustifolius in cereal-based (wheat/canola) cropping systems; they concluded that this significantly increased the yields and profitability of wheat/canola in the following two years. The results showed that field pea and lupin could supply $30-65 \mathrm{~kg} \mathrm{~N}^{-1}$ to the next crop and $60-110 \mathrm{~kg} \mathrm{~N}^{-1}$ to following crops (wheat/canola) for two years. Low soil moisture accessibility, low soil fertility are causes for low crop productivity in semiarid climate (Amanullah et al., 2012), beside the random use of chemical fertilizers by smallholders (Amanullah et al., 2015a). Further supply of nitrogen by enclosing legume crop in the cropping sequence involves no extra input and risk but may be a better replacement partly for chemical nitrogen. Incorporation of crop residues into the soil as a source of nutrients and management has been increasing in many parts of the world (Fischer et al., 2002). To reduce the application of fertilizers, soil incorporation of crop residues has been proposed as a method of ameliorate soil physical, chemical, and biological characters (Ercoli et al., 2008). In addition to the major nutrients (N, P and $\mathrm{K}$ ), crop residues have also considerable amounts of secondary nutrients and micronutrients, then returning back these residues into the soil may be one of the best alternative for improving the physical, chemical and biological properties of the deprived soils (Hiel et al., 2016). Dicotyledonous break crops are reported to enhance subsequent cereal yields by $15 \%$ to $25 \%$ because they decrease the possible impacts of pests, diseases and weeds, and enhance soil fertility "break-crop effect" (Kirkegaard et al., 2008). The nitrogen profit and break crop effects indicate that legume crops are an important factor in crop sequences and are recommended for inclusion into cereal-based cropping systems (Preissel et al., 2015). Organic applications increased nutrient status, microbial activity and productive possibility of soil (Kang et al., 2005). The microbial biomass control nutrient mineralization and is a small but labile source of the main plant nutrients (C, N, P and S) (Dick, 1992). Jastrow et al. (2007) suggested that the process of soil aggregation, which is a vital controller of soil organic matter dynamics and soil fertility, is expected to be strongly associated with changes in microbial communities. Microbial community roles, for example extracellular enzyme production, decomposition and production of aggregate binding agents, have before been linked to aggregate formation and soil organic matter accumulation (Tiemann and Grandy, 2015). Rhizosphere micro-organisms such as plant growth promoting rhizobacteria (PGPR) are known to 
enhance the process of biological nitrogen fixation by improving the number of nodules and biomass and promote nitrogenase activity by colonizing root system and inhibit growth of harmful organisms. Das and Singh (2014) studied the effects of PGPR and some types of organic manures (Farm yard manure, Cereal compost, Legume compost) on the nutrient content of plant and grain of mungbean in a field experiment. The maximum protein and total $\mathrm{N}, \mathrm{P}$ and $\mathrm{K}$ content of the stover were established in the plots receiving all the manures beside with co-inoculation of PGPR. In another study Amanullah et al. (2015b) observed that the integrated application of nitrogen (120 or $150 \mathrm{~kg} \mathrm{~N} \mathrm{ha}^{-1}$ ) along with compost $\left(2 \mathrm{tha}^{-1}\right)$ enhanced yield and it's components in maize. Therefore the current research work was performed to study the profitability of insertion legume crops (pea) in cereal-based cropping system, compared to incorporated heavy feeder crops (potato) with integrated nutrient management (bio, organic and inorganic fertilizers) on yield and it's components of the succeeding crop (maize). Moreover, the effect on soil organic matter level, microbial biomass, soil enzymes and microbial activities of the soil were studied in order to introduce a proper crop rotation system for higher maize productivity in the study area.

\section{Materials and Method Bacterial strains}

Two local rhizobial strains ARC-201 and 202 representing one species (Rhizobium leguminosarum) were used as rhizobial inoculum and three locally isolates of plant growth promoting rhizobacteria (PGPR) species (Serratia sp., Pseudomonas fluoresence and Paenibacillus polymyxa) were used as biofertilizer as recommended by El Sayed (2007). All strains were provided from the Microbiology Dep. Soils, Water and Environment Res. Inst., Agriculture Research Center (ARC), Giza, Egypt.

\section{Media used}

The following media were used for sub-culturing and maintenance of the investigated bacterial strains also determination and counting of the soil microbial biomass.

1- Yeast Extract Mannitol media (YEM) (Vincent, 1970), for rhizobial strains

2- Congo-red yeast extract mannitol agar medium, for counting rhizobia using the plate count technique. It was prepared by adding $15 \mathrm{~g} / \mathrm{L}$ agar and $10 \mathrm{ml}$ of $1 / 400$ aqueous solution of Congo-red to the YEM medium previously described. (Vincent, 1970)

3- Nutrient Agar (Atlas, 2004), for Paenibacillus polymexa,

4- Peptone glycerol medium (Grimont and Grimont, 1984), for Serratia $s p$.

5- Kings-agar B medium (Alef, 1995), for Pseudomonas fluorescence.

6- Rose Bengal agar media (Martin, 1950) for total count of fungi.

7- Jensen media (Allen, 1957) for total count of actinomycetes.

\section{Seeds}

One variety (master pea) of $\mathrm{Pe}$ sium sativum seeds and one variety (single hybrid 10) of Zea maize were obtained from Vegetables Research Dep., Horticultural Research Institute and Corn Research Dep., Field Crops 
Research Institute, ARC, Giza, Egypt, respectively.

\section{Compost used}

Compost used is prepared from rice straw, farmyard manure, elemental sulfur, rock phosphate, bentonite and finally bio-enriched with Tricoderma, Azotobacter and Bacillus. The main characteristics of the prepared bio-enriched compost are illustrated in Table 1.

Table 1. Some physical, chemical and microbiological properties of the prepared compost.

\begin{tabular}{|c|c|}
\hline Compost characteristic & Value \\
\hline \multicolumn{2}{|l|}{ Physical characters: } \\
\hline Bulk density $\left(\mathrm{Kg} / \mathrm{m}^{3}\right)$ & 568 \\
\hline Water holding capacity $(\%)$ & 172.5 \\
\hline \multicolumn{2}{|l|}{ Chemical analysis : } \\
\hline $\mathrm{pH}$ & 7.24 \\
\hline E.C $\left(\mathrm{dS} \mathrm{m}^{-1} 25^{\circ} \mathrm{C}\right)$ & 3.38 \\
\hline Total P (\%) & 0.67 \\
\hline Total K (\%) & 1.46 \\
\hline Available P (ppm) & 1.32 \\
\hline Available K (ppm) & 450.0 \\
\hline DTPA_extractable Fe (ppm) & 264.3 \\
\hline DTPA_extractable Zn (ppm) & 58.9 \\
\hline DTPA_extractable $\mathrm{Mn}(\mathrm{ppm})$ & 49.6 \\
\hline DTPA_extractable $\mathrm{Cu}(\mathrm{ppm})$ & 5.9 \\
\hline Organic matter $(\%)$ & 19.92 \\
\hline Total nitrogen $(\%)$ & 1.61 \\
\hline $\mathrm{C} / \mathrm{N}$ ratio & 12.37 \\
\hline \multicolumn{2}{|l|}{ Soluble nitrogen(ppm): } \\
\hline $\mathrm{NH}_{4}^{+}$ & 189.4 \\
\hline $\mathrm{NO}_{3}^{-}$ & 211.3 \\
\hline Total & 400.7 \\
\hline \multicolumn{2}{|l|}{ Biological analysis : } \\
\hline Total bacteria ( $\log$ No) & 7.54 \\
\hline Total fungi (log No) & 6.07 \\
\hline Total actinomycetes $(\log \mathrm{No})$ & 6.99 \\
\hline *Dehydrogenase activity & 164.7 \\
\hline$* * \mathrm{CO}_{2}$-evaluation rate & 2.11 \\
\hline
\end{tabular}

\section{Inoculum preparation}

To prepare inoculum of the bacterial strains under investigation, vermiculite provided with $10 \%$ Irish peat was packed in polyethylene bags, then sealed and sterilized by gamma irradiation $(5.0 \times 106$ rads $)$. $120 \mathrm{ml}$ of the tested bacterial culture $(1 \times 109 \mathrm{CFU} / \mathrm{ml})$ of each bacterial strain was injected into the sterilized carrier bags to satisfy $60 \%$ of their water holding capacity (107 cells/g carrier).

\section{Crop rotation experiment}

Legumes are a great crop alternate with heavier feeding plants and or N-demanding crops such as corn or potato. Moreover, bio and organic fertilizers were suggested to reduce the used N-mineral fertilizer quantities, as well as their effects on improving of nutrients availability, chemical and biological activity of the studied soil. Therefore, Rhizobium and PGPR were added as biofertilizers, compost and plant residues were used as organic fertilizer.

\section{Experimental design}

The experiments were conducted at Ismailia Experimental and Research Station, Ismailia Governorate, Egypt, during two successive seasons, winter (November) for pea and potato and summer (June) for corn. The experimental field was divided into two equal halves $600 \mathrm{~m}^{2}$ $(12 \mathrm{mx} 50 \mathrm{~m})$ to accommodate two rotation cycles. The experimental design was a split-split plot in the second phase of each rotation cycle. The main plot was the rotation system, compost represents the sub-plot and sub-sub plot was the different levels of nitrogen fertilizer $(30,60,90$ and $120 \mathrm{Kg}$ /fed ammonium sulphate). In the first phase of the two cycles, pea (Pisum sativum) (first plot) and potato (Solanum tuberosum vr. sponta) 
which was cultivated in other private experiment (second plot) were planted as the first crop. The two plots were amended with organic farm yard manure (FYM) and compost as organic matter, PGPR as biofertilizer and the recommended dose of mineral fertilizers. In the second phase of each rotation cycle, only corn (Zea maize) was planted on the two halves, soon after pea and potato harvest.

\section{The first phase of rotation cycle}

In the first plot, seeds of Pisum sativum (master pea variety) were inoculated with mixture of the two strains of Rhizobium leguminosarum (ARC-201 and 202) as a commercial inoculum. Seeds were further inoculated with the investigated PGPR strains (Serratia sp., Pseudomonas fluorescence and Paenibacillus polymyxa). The inoculation was done by mixing the gamma irradiated vermiculite based inoculum at rate of $600 \mathrm{~g} / 40 \mathrm{Kg}$ seeds before sowing. Recommended dose of mineral fertilization (NPK) was applied at the rate of $20 \mathrm{Kg} /$ fed ammonium sulphate $(20.6 \% \mathrm{~N}), 150 \mathrm{Kg} / \mathrm{fed}$ super phosphate $\left(15.5 \% \mathrm{P}_{2} \mathrm{O}_{5}\right)$ and $50 \mathrm{Kg} / \mathrm{fed}$ potassium sulphate $\left(48 \% \mathrm{~K}_{2} \mathrm{O}\right)$ before sowing. Plot treated with traditional fertilization dose $(100 \mathrm{Kg} \mathrm{N} / \mathrm{fed}$, FYM and rhizobial inoculant) was used as control. Seeds were sown on one side of ridges, ridges was $60 \mathrm{~cm}$ width and $4 \mathrm{~m}$ length and $25 \mathrm{~cm}$ apart. Each plot included 4 ridges and the plot size was $600 \mathrm{~m}^{2}$, sprinkler irrigation was applied.

\section{The second phase of the rotation cycle}

The two plots (previously occupied by pea and potato) of the ex- perimental field were divided into two sub-plots, the two sub-plots were developed in such a manner that half of the legume and potato plots were given compost (recommended dose 5 ton/fed) (Abdel Wahab, 2008) seven days prior of sowing. Then after full dose of phosphate and one third of potassium were applied at final land preparation as a basal dose, the remaining two third dose of potassium was applied at 70 days after sowing. Phosphate was added in the form of super-phosphate $(200 \mathrm{Kg}$ /fed $15.5 \%$ $\mathrm{P} 2 \mathrm{O} 5)$ potassium in the form of potassium sulphate $(50 \quad \mathrm{Kg} / \mathrm{fed}$ $48 \% \mathrm{~K}_{2} \mathrm{O}$ ). Nitrogen fertilization rates were full dose of nitrogen $120 \mathrm{Kg} / \mathrm{fed}$ $(100 \%)$ as well as three reduced doses $90 \mathrm{Kg} /$ fed $(75 \%), 60 \mathrm{Kg} /$ fed $(50 \%)$ and $30 \mathrm{Kg} / \mathrm{fed}(25 \%)$. Nitrogen fertilizer was applied in four equal doses at 15, 30, 45 and 60 days after planting. The remaining plant residues of the previous crop (legume) were incorporated into the soil by rotovator before maize planting. To examine the effect of legume in rotation on maize plant productivity and soil status, plant samples were collected at harvest stage (120 days) for evaluation of different yield parameters (grain yield, stalk yield, length, diameter and weight of ear, 100 grains weight, $\mathrm{N}, \mathrm{P}, \mathrm{K} \%$ and crude protein of stalk and grains). The improvement in nutrients availability and the enhancement in microbial activities of the soil were studied as well.

\section{Soil analysis}

Representative surface soil samples $(20 \mathrm{~cm}$ depth) were collected from the experimental sites before maize planting (after potato and pea 
harvest) for physical, chemical and microbiological assays (Table 2). Also, rhizosphere soil samples were chemically and biologically analyzed after maize harvest.

Table 2. Physical, chemical and microbiological analysis of the studied soil area.

\begin{tabular}{|c|c|}
\hline Soil characteristic & Value \\
\hline \multicolumn{2}{|l|}{ Particle size distribution: } \\
\hline Sand $(\%)$ & 90.51 \\
\hline Slit (\%) & 2.21 \\
\hline Clay $(\%)$ & 7.28 \\
\hline Texture grade & Sandy \\
\hline \multicolumn{2}{|l|}{ Chemical characters: } \\
\hline Saturation percent (S.P \%) & 20.20 \\
\hline $\mathrm{pH}$ & 7.70 \\
\hline E.C $\left(\mathrm{dS} \mathrm{m}^{-1} 25^{\circ} \mathrm{C}\right)$ & 0.22 \\
\hline \multicolumn{2}{|l|}{ Soluble cations (meq/L) } \\
\hline $\mathrm{Ca}^{++}$ & 0.67 \\
\hline $\mathrm{Mg}^{++}$ & 0.46 \\
\hline $\mathrm{Na}^{+}$ & 1.32 \\
\hline $\mathrm{K}^{+}$ & 0.45 \\
\hline \multicolumn{2}{|l|}{ Soluble anions (meq/L): } \\
\hline $\mathrm{CO}^{-2}$ & -- \\
\hline $\mathrm{HCO}^{-}$ & 1.69 \\
\hline $\mathrm{Cl}^{-}$ & 0.62 \\
\hline $\mathrm{SO}_{4}^{-2}$ & 0.59 \\
\hline Organic matter $(\%)$ & 0.21 \\
\hline Total nitrogen (ppm) & 233.30 \\
\hline $\mathrm{C} / \mathrm{N}$ ratio & 10.36 \\
\hline \multicolumn{2}{|l|}{ Soluble nitrogen (ppm): } \\
\hline $\mathrm{NH}_{4}^{+}$ & 12.23 \\
\hline $\mathrm{NO}^{-}$ & 6.76 \\
\hline Total & 28.50 \\
\hline Available P (ppm) & 9.82 \\
\hline Available K (ppm) & 94.00 \\
\hline \multicolumn{2}{|l|}{ Biological characters: } \\
\hline Total bacteria (log No.) & 5.40 \\
\hline Total fungi (log No.) & 3.21 \\
\hline Total actinomycetes (log No.) & 4.20 \\
\hline *Dehydrogenase activity & 35.33 \\
\hline$* * \mathrm{CO}_{2}$-evaluation rate & 4.82 \\
\hline
\end{tabular}

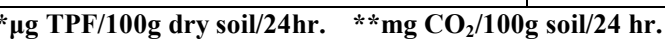

1-Soil chemical determinations

a) $\mathrm{pH}$ was measured in soil water suspension $(1: 2.5)$ using glass electrode $\mathrm{pH}-$ meter and electrical conductivity as well as soluble ions in soil paste extracts (Jackson, 1973).

b) Organic carbon was determined by Walkly and Black method as described by Black et al. (1965).

c) Total nitrogen was determined using the macro Kjeldahl method. (Jackson, 1973).

d) Total soluble nitrogen was determined by steam distillation procedure using Mg- Deverda alloy (Black et al., 1965).

e) Available phosphorus was determined using Spectrophotometer at wave length $640 \mathrm{~nm}$. (Page $e t$ al., 1982).

f) Available potassium was determined using Flame phtometer (Page et al., 1982).

\section{2-Evaluation of soil biological ac- tivity}

The soil biological activity was taken as a biological tool for estimating the differences occurred in soil fertility between the two studied rotation cycles.

\section{a) Microbial enumeration}

Soil samples were microbiologically analyzed for densities of mesophilic bacteria, fungi and actinomycetes. Total count technique was employed to enumerate the groups of soil microorganisms (Page et al., 1982).

\section{b) Carbon dioxide evolution}

Soil samples were estimated for carbon dioxide evolution by soil microorganisms according to Page et al. (1982). 


\section{c) Dehydrogenases activity}

Activity was assayed according to Casida (1977).

\section{Plant measurements}

\section{a) Nitrogen $\%$}

Nitrogen $\%$ of plant material was determined using wet digestion by mixture consist of perchloric $\left(\mathrm{HClO}_{4}\right)$ and sulfuric acid $\left(\mathrm{H}_{2} \mathrm{SO}_{4}\right)$ at ratio $1: 1$ by volume as described by Jackson (1973). The N-concentration was measured in the digested solution using Macro-Kjeldahl method according to Page et al. (1982).

\section{b) Phosphorus and Potassium \%}

$\mathrm{P}$ and $\mathrm{K} \%$ in plant material were determined in the digested solution using stannus chloride reagent by spectrophotometer at $640 \mathrm{~nm}$ for phosphorus and using flame photometer for potassium according to Page et al. (1982).

\section{d) Crude protein}

Crude protein of seeds and straw was calculated by multiplying the nitrogen content (expressed in percentage) by 6.25 .

\section{e) Chlorophyll content}

Fresh leaf sample $(0.5 \mathrm{gm})$ was extracted by $20 \mathrm{ml} 80 \%$ methanol after grinding. The sample was filtered through filter paper. The absorption of constant volume of filtered was measured at optical density 650 and $665 \mathrm{~nm}$ (Arnon, 1949). Total chlorophyll was calculated by the following equation:

Total chlorophyll $(\mathrm{mg} / \mathrm{L})=25.5 \mathrm{D}$ $650+4.0$ D 665

\section{f) Root surface area}

It was measured by the titration method as described by Wilde and Voigt (1949). Air-dried root system was immersed in a solution of $3 \mathrm{~N}$ $\mathrm{HCl}$ for 15 seconds. Then the roots were drained for 5 minutes to remove excess acid then were transferred to a beaker containing $250 \mathrm{ml}$ of distilled water. The contents of the beaker were stirred to wash the acid from the roots and then allowed to stand for at least 10 minute. $100 \mathrm{ml}$ aliquot of the weak acid solution was tittered with $0.3 \mathrm{~N} \mathrm{NaOH}$ and phenolphthalein indicator. The relative area of the root surface expressed in $\mathrm{ml}$ of $\mathrm{NaOH}$ that used in acid titration.

\section{g) Nitrogenase enzyme activity}

The nitrogenase activity of mature roots nodules was estimated using the acetylene reduction assay method according to Hardy et al. (1973).

\section{Statistical analyses}

The mean values of triplicates data of different parameters were submitted to analysis of variance (ANOVA) the treatment means were compared according to the procedures outlined by Snedecor and Cochran (1980).

\section{Results and Discussion}

Maize was grown in plots had previously cultivated by pea and potato, the remaining legume residues were incorporated into the soil. Four $\mathrm{N}$-rates (30, 60, 90 and $120 \mathrm{Kg} / \mathrm{fed}$.) were compared; recommended phosphorus and potassium were applied to all plots. Half of each plot was given compost as recommended.

NPK accumulation and yield response of maize to nutrient management in different cropping systems.

\section{A- Main effect}

In respect to the main effect of either inorganic-N addition, organic manure or rotation system data present in Tables 3 and 4 reveal that they achieve positive effect on maize yield 
and its components as well as NPK grain accumulation when they applied solely. Many researchers have reported that $\mathrm{N}$ is a key factor in the response of cereals following legumes compared with cereals following non-legumes (Chalk et al., 1993 and Smiley et al., 1994). Currently a good response was detected for plots receiving a supply of manure or un- der legume rotation sequence. In accordance, Chen (1993) illustrated that legume can provide $15 \mathrm{~T} / \mathrm{ha}$ biomass and quick decomposition of which is possible with easy releasing of the available nutrients responsible to create an increase of $810 \mathrm{~kg} / \mathrm{ha}$ grain yield of wheat and maize in the next season.

Table 3. Main effect of inorganic $N$, compost and rotation system on yield and its attributes of maize plants.

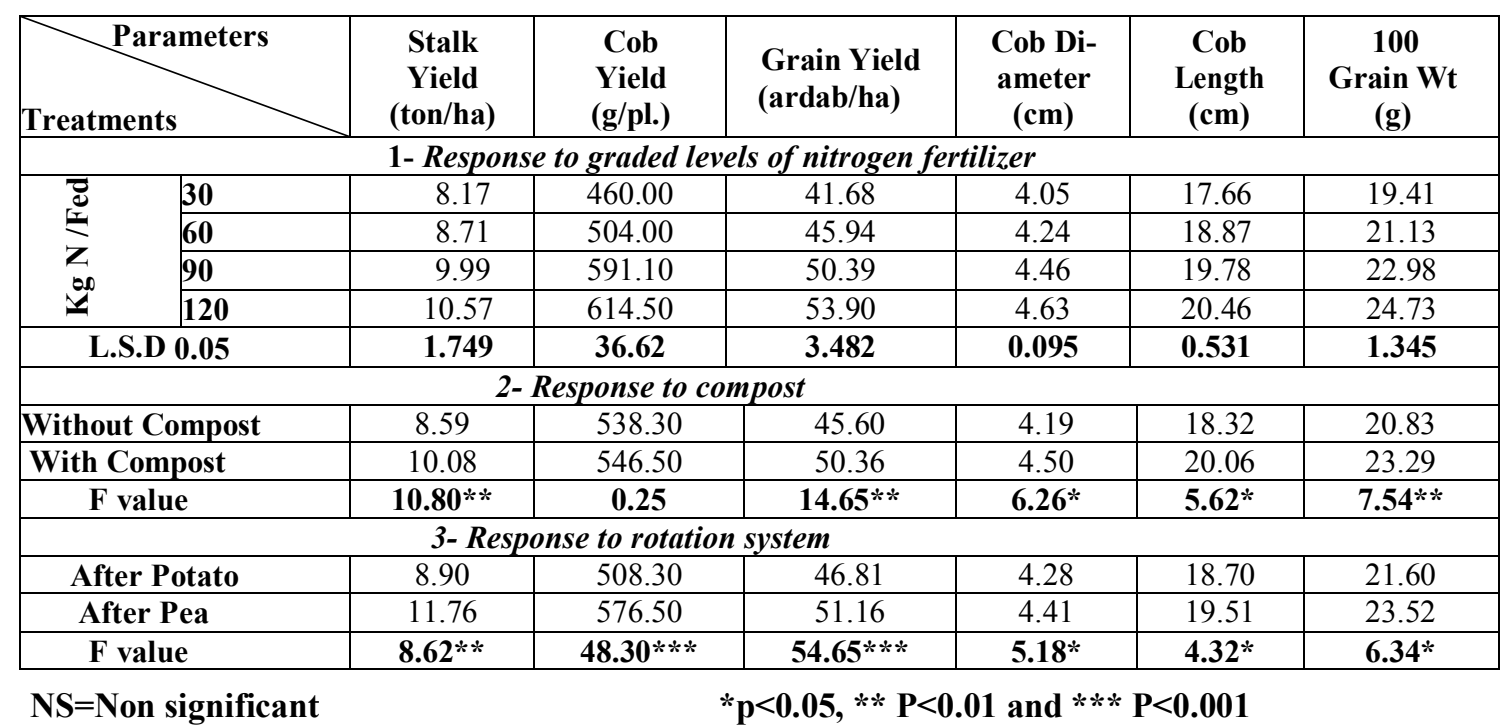

Table 4. Main effect of inorganic $N$, compost and rotation system on \% NPK status of maize yield

\begin{tabular}{|c|c|c|c|c|c|c|c|}
\hline$\overbrace{\text { Treatments }}^{\text {Pa }}$ & & $\begin{array}{l}\text { Stalk } \\
\text { Crude } \\
\text { Protein }\end{array}$ & $\begin{array}{c}\text { Grain } \\
\text { Crude } \\
\text { Protein }\end{array}$ & Stalk P & Grain P & Stalk K & Grain K \\
\hline & & 1- Respc & graded l & s of nitrog & ertilizer & & \\
\hline z & 30 & 3.91 & 9.01 & 0.076 & 0.123 & 0.737 & 0.497 \\
\hline 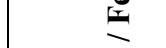 & 60 & 4.28 & 10.60 & 0.091 & 0.145 & 0.844 & 0.942 \\
\hline$Z_{0 \infty}$ & 90 & 5.01 & 11.08 & 0.143 & 0.169 & 0.907 & 1.234 \\
\hline & 120 & 5.61 & 11.69 & 0.248 & 0.207 & 0.980 & 1.460 \\
\hline L.S.D & & 0.149 & 0.336 & *NS & 0.0263 & 0.0263 & 0.0263 \\
\hline & & & 2- Resp & e to compo & & & \\
\hline Without Co & & 4.295 & 9.967 & 0.115 & 0.1604 & 0.728 & 0.967 \\
\hline With Com & & 5.109 & 11.23 & 0.1633 & 0.1612 & 1.010 & 1.100 \\
\hline F valu & & $6.54 *$ & $8.42 * *$ & 0.45 & 0.26 & $5.62 *$ & 3.14* \\
\hline & & & onse to $r$ & on system & & & \\
\hline After Po & & 4.561 & 10.220 & 0.113 & 0.145 & 0.812 & 0.708 \\
\hline After $F$ & & 4.843 & 10.980 & 0.166 & 0.177 & 0.922 & 1.359 \\
\hline F valu & & $3.62 *$ & $4.50 *$ & 0.19 & $4.52 * *$ & $4.64 \%$ & $5.72 *$ \\
\hline
\end{tabular}




\section{B- Interaction effect}

\section{1- Yield and yield components.}

Data in Table 5 reveal that maize yield and its components responded positively to the proper crop rotation and fertilization management. The higher values of all investigated parameters were recorded for the composted legume/cereal cropping system in which residues were incorporated with nitrogen application at the rate of $120 \mathrm{Kg} \mathrm{N} / \mathrm{fed}$. The plots of potato/cereal cropping system in which no residues and compost were included responded poorly and resulted in least mean values of yield parameters. Kouyaté et al. (2000) suggested that yield increases may be due to the increased accessibility of mineral nitrogen provided by mineralization of legume residues. Result of the present investigation showed that at harvest the yield of composted maize significantly increased in pea rotation by $28.46 \%$ for stalk yield $15.48 \%$ for grain yield, $18.21 \%$ for cob yield, $4.89 \%$ for cob diameter, $1.74 \%$ for cob length and finally $12.40 \%$ for 100 grain weight at $120 \mathrm{Kg} \mathrm{N} /$ fed. over composted maize in potato rotation at the same $\mathrm{N}$ level. These results are in agreement with Horst and Hardter (1994) who recorded a significant increase in maize grain yields when maize was planted in rotation with cowpea than for maize monocropping, which was due to the incorporation of plant residues of cowpea, which returning high amounts of nitrogen to the soil. Results were also in line with that obtained by Muhammad et al. (2011), who reported that maize grain yield and yield components were mostly higher in legume-cereal (chickpea- maize) cropping system complemented with nitrogen. Meng et al. (2012) illustrated that legume rotation stimulate cereal growth and yield increases seemed to depend on the capability of the legume to enhance early $\mathrm{N}$ and $\mathrm{P}$ availability for the following cereal. Better management of high yielding crops with lower inorganic $\mathrm{N}$ was detected (Table 5), the parameters like cob diameter, 100 grain weight and grain yield in pea/corn rotation for the composted plants at $90 \mathrm{Kg} \mathrm{N} / \mathrm{fed}$., showed no significant differences compared to that obtained for the same treatment at $120 \mathrm{Kg} \mathrm{N} / \mathrm{fed}$. which indicated that legume (pea) inclusion in rotation supplied about $30 \mathrm{Kg} /$ fed. less $\mathrm{N}$ to the subsequent crop. Thus, the probable reason for more grain yield could be the more number of grains /cob and more 100 grain weight since more cob diameter was recorded. This result reflects the noticed support of compost for the maize yield and its attributes particularly under desert soil conditions (Abdel-Wahab et al., 2002). One of the most important earlier explanations observed by Herridge et al. (1995) is that nitrogen "sparing" is another way in which legume crops add $\mathrm{N}$ to intercrop or rotation crops. Since part of their N requirement is met by $\mathrm{N}_{2}$ fixation, legumes utilize less of the available soil $\mathrm{N}$ than cereals, thereby save or preserve inorganic $\mathrm{N}$ for the following crop. Stanger and Lauer (2008) illustrated that if $\mathrm{N}$ is the only cause of yield differences between rotations, then these differences would be expected to disappear if more than sufficient $\mathrm{N}$ is applied, it is clear that $\mathrm{N}$ fertilizers do not substitute for crop 
rotation. The obtained results are also in good accordance with results achieved by Sharifi and Taghizadeh (2009) who observed an increased ear diameter and ear length with increasing $\mathrm{N}$ level. Rehman et al. (2010) explained that the increases in grains yield were probably due to the more number of rows per ear, or number of grain per row. Xing et al. (2017) reported that the direct $\mathrm{N}$ benefit of grain legumes to the succeeding crops would be invisible when $\mathrm{N}$ fertilizer was applied over the optimal level. Considering the beneficial impact of organic fertilizer (compost and plant residues), it can be concluded from the current results that composted maize in pea rotation at $120 \mathrm{Kg}$ $\mathrm{N} /$ fed. achieved significantly higher stalk yield, grain yield, cob diameter and 100 grain weight by $52.84,14.61$, 7.17 and $11.78 \%$ respectively than the non-composted ones. At the same time, maize after potato grown without organic fertilizer produced considerably lower yield compared to that after pea with organic compost. Rhizosphere studies made by Gan et al. (2015) showed that the effects on soil $\mathrm{pH}$ and acid phosphatase activity were secondary causes for the observed growth difference between rotated cereals and continuous cereals. Recently, Ashworth et al. (2016) showed that including soybean twice within a 4-yr rotation increased corn yield by $6 \%$ compared to continuous corn across 12 year. Xing et al. (2017) concluded that field pea and lupin could contribute $30-65 \mathrm{~kg} \mathrm{~N}$ $\mathrm{ha}^{-1}$ to the next crop and $60-110 \mathrm{~kg}$ $\mathrm{N}$ ha ${ }^{-1}$ to subsequent crop for two years, corresponding to $30-55 \%$ and $60-86 \%$ of net $\mathrm{N}$ inputs of legumefixed $\mathrm{N}$, respectively.

Table 5. Interaction effect of inorganic $N$, compost and rotation system on yield and its attribute of maize plants grown in sandy soil

\begin{tabular}{|c|c|c|c|c|c|c|c|c|c|c|c|c|}
\hline \multirow{2}{*}{ Kg $\mathrm{N} / \mathrm{fed}$} & \multicolumn{2}{|c|}{$\begin{array}{c}\text { Stalk Yield } \\
\text { (ton/ha) }\end{array}$} & \multicolumn{2}{|c|}{$\begin{array}{l}\text { Grain Yield } \\
\text { (ardab/ha) }\end{array}$} & \multicolumn{2}{|c|}{ Cob Yield (g/pl) } & \multicolumn{2}{|c|}{$\begin{array}{c}\text { Cob Diameter } \\
\text { (cm) }\end{array}$} & \multicolumn{2}{|c|}{$\begin{array}{l}\text { Cob Length } \\
\text { (cm) }\end{array}$} & \multicolumn{2}{|c|}{$\begin{array}{c}100 \text { Grains Wt } \\
(\mathrm{g})\end{array}$} \\
\hline & $\begin{array}{c}\text { After } \\
\text { Pea }\end{array}$ & $\begin{array}{c}\text { After } \\
\text { Potato }\end{array}$ & $\begin{array}{c}\text { After } \\
\text { Pea }\end{array}$ & $\begin{array}{c}\text { After } \\
\text { Potato }\end{array}$ & $\begin{array}{c}\text { After } \\
\text { Pea }\end{array}$ & $\begin{array}{c}\text { After } \\
\text { Potato }\end{array}$ & $\begin{array}{l}\text { After } \\
\text { Pea }\end{array}$ & $\begin{array}{c}\text { After } \\
\text { Potato }\end{array}$ & $\begin{array}{c}\text { After } \\
\text { Pea }\end{array}$ & $\begin{array}{l}\text { After } \\
\text { Potato }\end{array}$ & $\begin{array}{c}\text { After } \\
\text { Pea }\end{array}$ & $\begin{array}{l}\text { After } \\
\text { Potato }\end{array}$ \\
\hline \multicolumn{13}{|c|}{ With Compost } \\
\hline 30 & 9.22 & 8.11 & 44.04 & 41.79 & 518.50 & 417.00 & 4.17 & 4.17 & 18.00 & 17.77 & 21.60 & 19.43 \\
\hline 60 & 9.73 & 8.85 & 49.17 & 46.46 & 550.20 & 468.70 & 4.40 & 4.37 & 20.27 & 19.47 & 22.43 & 22.03 \\
\hline 90 & 11.73 & 10.06 & 54.71 & 49.75 & 636.70 & 546.70 & 4.83 & 4.53 & 21.23 & 20.93 & 24.40 & 22.4 \\
\hline 120 & 13.45 & 10.47 & 58.41 & 50.58 & 652.20 & 551.70 & 4.93 & 4.70 & 21.60 & 21.23 & 26.27 & 23.37 \\
\hline \multicolumn{13}{|c|}{ Without Compost } \\
\hline 30 & 7.90 & 7.45 & 41.25 & 39.66 & 471.20 & 433.30 & 3.967 & 3.900 & 17.33 & 17.53 & 18.90 & 17.70 \\
\hline 60 & 8.19 & 8.06 & 45.12 & 43.04 & 527.00 & 470.00 & 4.133 & 4.067 & 18.10 & 17.63 & 20.80 & 18.90 \\
\hline 90 & 8.30 & 8.39 & 48.62 & 46.50 & 622.90 & 558.30 & 4.33 & 4.23 & 19.00 & 17.97 & 22.27 & 21.53 \\
\hline 120 & 8.80 & 8.64 & 50.96 & 48.67 & 632.50 & 590.90 & 4.60 & 4.30 & 20.57 & 18.43 & 23.50 & 23.07 \\
\hline L.S.D. 0.05 & \multicolumn{2}{|c|}{3.45} & \multicolumn{2}{|c|}{7.44} & \multicolumn{2}{|c|}{68.41} & \multicolumn{2}{|c|}{0.19} & \multicolumn{2}{|c|}{1.08} & \multicolumn{2}{|c|}{2.69} \\
\hline
\end{tabular}

\section{2-NPK accumulation}

Concentrations of some major nutrient elements in maize grain yield were evaluated; increasing $\mathrm{N}$ fertilizer rates promote significant increase in total nutrient uptake. Maximum NPK content were produced by the higher nitrogen application $(120 \mathrm{Kg}$ /fed.). Data in Table, 6 reveal that significant increases in nutrient ac- 
cumulation can be observed for the composted maize yield (stalk and grains) at $120 \mathrm{Kg} \mathrm{N} / \mathrm{fed}$. in the pea rotation compared with the corresponding non-composted ones. The percentage increases are 13.42 and $16.55 \%$, for stalk and grain crude protein, 94.17 and $15.66 \%$ for stalk and grain $\mathrm{P} \%$ and 66.92 and $52.24 \%$ for stalk and grain $\mathrm{K} \%$ in respective order. A possible reason suggested by Bakhtiar et al. (2005) and Yaseen et al. (2006) illustrated that application of organic fertilizer in combination with mineral fertilizer have been found to increase absorption of $\mathrm{N}, \mathrm{P}$ and $\mathrm{K}$ in various crops as compared with chemical fertilizer alone. In accordance, Bokhtiar and Sakurai (2005) also illustrated that plant uptake of N, P and K was reported to be at maximum with application of farmyard manure accomplished with $120 \mathrm{~kg} \mathrm{~N} / \mathrm{ha}$. In addition, Abedi et al. (2010) recommended using combination of organic and inorganic fertilizer to realize highest yield without negative effect on seed quality, it is assumed that the compost application lead to grain protein content en- hancement due its effect on soil structure and consequently increase in plant nutrients uptake. It is worthy mentioned that NPK accumulation in non-composted maize under investigation for potato rotation at $120 \mathrm{Kg} \mathrm{N}$ /fed. were highly significant lower when compared to the composted maize in pea rotation and receiving the same $\mathrm{N}$ dose. Stalk and grain crude protein, stalk and grain $\mathrm{P} \%$ and stalk and grain $\mathrm{K} \%$ were lower by $22.53,17.99,45,21.51,42.95$ and $72.22 \%$ in respective order. Obviously, it seems the crop sequences may suggested to effect macronutrients accumulation. Lupwayi et al. (2011) demonstrated that roots of non-legumes grown in rotation with legumes contain endophytic rhizobia which act as plant growth promoting rhizobacteria that lead to spread out the root of the crop, enhancing nutrients uptake which enabling those plants to accumulate more N, P, K, $\mathrm{Ca}, \mathrm{Mg}$ and $\mathrm{Na}$. This suggests that contribution of rhizobia to the rotational benefits of legumes in cropping systems is in more ways than just fixing $\mathrm{N}_{2}$.

Table 6. Interaction effect of inorganic $\mathrm{N}$, compost and rotation system on \% NPK status of maize yield

\begin{tabular}{|c|c|c|c|c|c|c|c|c|c|c|c|c|}
\hline \multirow{2}{*}{ Kg N/fed } & \multicolumn{2}{|c|}{\begin{tabular}{|c|}
$\begin{array}{c}\text { Stalk Crude } \\
\text { Protein }\end{array}$ \\
\end{tabular}} & \multicolumn{2}{|c|}{$\begin{array}{c}\text { Grain crude } \\
\text { Protein } \\
\end{array}$} & \multicolumn{2}{|c|}{ Stalk P } & \multicolumn{2}{|c|}{ Grain $P$} & \multicolumn{2}{|c|}{ Stalk K } & \multicolumn{2}{|c|}{ Grain K } \\
\hline & $\begin{array}{l}\text { After } \\
\text { Pea }\end{array}$ & $\begin{array}{c}\text { After } \\
\text { potato }\end{array}$ & $\begin{array}{c}\text { After } \\
\text { Pea }\end{array}$ & $\begin{array}{l}\text { After } \\
\text { Potato }\end{array}$ & $\begin{array}{c}\text { After } \\
\text { Pea }\end{array}$ & $\begin{array}{l}\text { After } \\
\text { Potato }\end{array}$ & $\begin{array}{c}\text { After } \\
\text { Pea }\end{array}$ & $\begin{array}{l}\text { After } \\
\text { Potato }\end{array}$ & $\begin{array}{c}\text { After } \\
\text { Pea }\end{array}$ & $\begin{array}{l}\text { After } \\
\text { Potato }\end{array}$ & $\begin{array}{l}\text { After } \\
\text { Pea }\end{array}$ & $\begin{array}{l}\text { After } \\
\text { Potato }\end{array}$ \\
\hline \multicolumn{13}{|c|}{ With Compost } \\
\hline 30 & 4.27 & 3.94 & 10.00 & 10.13 & 0.132 & \begin{tabular}{|l|l|}
0.063 \\
\end{tabular} & 0.172 & 0.100 & 0.790 & 0.790 & 0.509 & \begin{tabular}{|l|l|}
0.487 \\
\end{tabular} \\
\hline 60 & 4.68 & 4.31 & 11.13 & 10.97 & 0.140 & 0.080 & 0.182 & 0.120 & 1.100 & 820 & 1.687 & 0.69 \\
\hline 90 & 5.80 & 5.68 & 11.80 & 11.10 & 0.144 & 0.090 & 0.248 & 30 & 1.157 & 993 & 2.083 & 1.00 \\
\hline 120 & \begin{tabular}{|l|l|}
6.17 & - \\
\end{tabular} & 6.03 & 13.17 & 11.50 & 0.200 & \begin{tabular}{|l|l|}
0.157 \\
\end{tabular} & 0.251 & 0.187 & 1.297 & .110 & 2.340 & 1.315 \\
\hline \multicolumn{13}{|c|}{ Without Compost } \\
\hline 30 & \begin{tabular}{|l|}
3.93 \\
\end{tabular} & 3.50 & 8.77 & 7.13 & 0.052 & 0.054 & 0.117 & 0.098 & 0.740 & .633 & 0.505 & 0.49 \\
\hline 60 & 4.13 & 4.01 & 10.50 & 9.80 & 0.062 & \begin{tabular}{|l|l|}
0.082 \\
\end{tabular} & 0.138 & 0.139 & 0.753 & 03 & 0.890 & 0.503 \\
\hline 90 & 4.33 & 4.24 & 11.13 & 10.30 & 0.065 & \begin{tabular}{|l|l|}
0.090 \\
\end{tabular} & 0.183 & 0.178 & 0.767 & 0.713 & 1.317 & \begin{tabular}{|l|l|}
0.537 \\
\end{tabular} \\
\hline 120 & 5.44 & 4.78 & 11.30 & 10.80 & 0.103 & 0.110 & 0.217 & $\mid 0.197$ & 0.777 & $\mid 0.740$ & 1.537 & 0.65 \\
\hline L.S.D 0. & \multicolumn{2}{|c|}{0.2881} & \multicolumn{2}{|c|}{0.8722} & \multicolumn{2}{|c|}{0.05259} & \multicolumn{2}{|c|}{5259} & \multicolumn{2}{|r|}{259} & \multicolumn{2}{|r|}{5259} \\
\hline
\end{tabular}


3- Impact of rotation program on soil chemical and biological properties of soil corn rhizosphere.

Most of the horizontal extension in Egypt for plant production is carried out in newly reclaimed soils particularly in sandy ones which suffer from structure, nutritional problems and alkaline $\mathrm{pH}$. Soils will not be appropriate for crop production if they lack main nutrients. Soil fertility management is an essential part of successful crop production, nutrients must be available in adequate and balanced quantities. Data recorded in (Table 7) illustrate that cultivation of legumes in sandy soil resulted in an increase of soil organic carbon (SOC) content as well as essential nutrients (NPK) after harvest as compared to the initial situation (Table 8). Differences in $\mathrm{pH}$ as well as EC values among investigated treatments were not statistically significant (Table 7). Furthermore, no significant differences were also detected for soil $\mathrm{pH}$ after pea or potato harvest (Table 8) and $\mathrm{pH}$ values of soil corn rhizosphere for all investigated treatments. However, the numerical values of the $\mathrm{pH}$ were a bit lower for composted plots. While a remarkable decrease was noticed when compared with the initial soil $\mathrm{pH}$ (7.7) before cultivation (Table 8). Sarwar et al. (2008a) illustrated that soil pH is the single soil characteristic, which point out an overall picture of the medium for plant growth including nutrient supply trend, salinity, sodicity status and soil mineralogy. Yaduvanshi (2001) concluded a decrease in soil $\mathrm{pH}$ after the use of organic materials he suggested that the production of organic acids during mineralization of organic materials would have caused the decrease in soil $\mathrm{pH}$ value. Similarly, Sarwar et al. (2008a) concluded that application of compost alone and in combination with chemical fertilizer reduced the soil $\mathrm{pH}$ significantly as compared to control. In general, Electrical conductivity is a soil parameter that indicates indirectly the total concentration of soluble salts and is a direct measurement of salinity. The recorded EC of the experimental soil tend to increase in the composted plots. In accordance, a study conducted by Sarwar et al. (2008b) illustrated that the decomposition of organic materials released acids or acid forming compounds that react with the soluble salts already present in the soil and either converted them into soluble salts or at least increased their solubility therefore, the EC of soil was increased. Results also illustrated that legume/cereal cropping system and combined application of compost with inorganic $\mathrm{N}$ fertilizer maintained the higher soil nutrients content. Data present in (Table 7) illustrate significant difference in residual SOC left, total nitrogen (TN) and available NPK compared to soil before cultivation (Table 8). Treatments receiving compost in combination with 120 or $90 \mathrm{Kg} \mathrm{N} /$ fed. after pea cultivation recorded the maximum values. Results were in good accordance with Senigagliesi and Ferrari (1993) who found that the crop/pasture with legume rotation increased the organic matter in soil by $46.7 \%, \mathrm{~N}$ by $48.3 \%$ and $\mathrm{P}$ by $76.0 \%$ with respect to original contents. Soil organic carbon and TN values for the investigated experimental soil before cultivation were 
$0.21 \%$ and $233.3 \mathrm{ppm}$ respectively. An increase reached $161.9 \%$ for SOC and $120.01 \%$ for TN were detected for treatment of $120 \mathrm{Kg} \mathrm{N} /$ fed. with compost in pea rotation. While comparable with composted plots in potato rotation at $120 \mathrm{~kg} \mathrm{~N} / \mathrm{fed}$. SOC and $\mathrm{TN}$ increased by $100 \%$ and $29.87 \%$ only. Cazzato et al. (2012) illustrated that soil $\mathrm{N}$ loss may be minimized by using valuable legume crops which can supply sufficient $\mathrm{BNF}$ input to enhance soil $\mathrm{N}$ by improved recycling of $\mathrm{N}$ through plant residues. Furthermore, results obtained by Rutkowska and Pikula (2013) pointed that the most important factor which stabilizes organic carbon content in agricultural soils was crop rotation with legumes. On the other hand, a detected positive impact was observed in soil organic built up status and soil total $\mathrm{N}$ for soil under investigation while using the proper rotation cycle (legume /cereal) especially with organic matter addition (taking in consideration that pea plant residues were incorporated into soil after pea harvest). May the present results demonstrated only little improvement in soil $\mathrm{C}$ and $\mathrm{N}$ content for the composted plots at pea rotation. It is however, expected that the improvement of soil organic matter and $\mathrm{N}$ content will be more obvious in long term experiments. It is believed that organic matter in soil is typically slow to respond to management changes and treatment effects and may not be easily estimated within a short period of time. Foley and Cooperband (2002) suggested that the greatest improvement in water retention resulted soon after application of different organic composts.
Brady and Weil (2005) explained that soil organic matter encourages granulation, increases cation exchange capacity and responsible for adsorbing power of the soils up to $90 \%$. Concerning soil available nutrients changes, data recorded indicated that the higher soil available nitrogen values were obtained for the plots received $120 \mathrm{Kg} \mathrm{N} /$ fed. after pea cultivation either composted (55.10 ppm) or non-composted (53.90 ppm).This increase reached about two-fold when compared to initial available soil $\mathrm{N}$ before cultivation (28.56) (Table 8). Moreover, the percentage increase of $\mathrm{P}$ over the initial value (soil before cultivation) was found to be $31.36 \%$ at $120 \mathrm{Kg} \mathrm{N} /$ fed. and $30.34 \%$ at 90 $\mathrm{Kg} \mathrm{N} /$ fed. While the percentage increase of $\mathrm{K}$ was $29.14 \%$ at $120 \mathrm{Kg}$ $\mathrm{N} / \mathrm{fed}$. and $25.21 \%$ at 90 of $\mathrm{Kg}$ $\mathrm{N} /$ fed., which is in consistent with results obtained for yield parameters. In accordance Jayathilake et al. (2006) demonstrated that the available $\mathrm{P}$ and $\mathrm{K}$ were highest when organic matter and chemical fertilizer were applied to the soil, than in soil with chemical fertilizer only. They suggested that the built up of available $\mathrm{P}$ and $\mathrm{K}$ in soil could be due to the organic acids which were released during microbial decomposition of organic matter, and increasing the available $\mathrm{P}$ and $\mathrm{K}$. These agreed with Sarwar et al. (2008b) who reported that phosphorus status of the soil was found to be improved significantly as well as water soluble potassium, when chemical fertilizer and compost were added to the soil after wheat harvest in rice /wheat rotation. They assumed that the hydrogen ions released from organic materials are ex- 
changed with $\mathrm{K}$ on exchange site or set free from the fixed site of soil particles, thus the overall status of soil available $\mathrm{K}$ is improved. The living fraction of organic matter (the microbial biomass) responds much more quickly to changes in crop management or environmental conditions than soil organic matter (Doran et al., 1996). In this context, the biological activity of the current experimental soil as expressed through number of microorganisms, production of $\mathrm{CO}_{2}$ and enzymatic activity were generally higher in the pea rotation system and co-application of enriched compost with inorganic $\mathrm{N}$ fertilizer treatment (Table 7). This was in line with Tilman et al. (2006) who noticed that belowground benefits of rotational plant diversity have been linked to changes in microbial communities. Further, McDaniel et al. (2014) illustrated that crop rotations increase microbial biomass by an average $21 \%$. The current result showed also that the highest $\mathrm{CO}_{2}$ evolution was observed at 120 and $90 \mathrm{Kg} \mathrm{N} /$ fed. this was in parallel with microbial biomass and dehydrogenase activity. It is obviously shown that dehydrogenase in rhizosphere soil with organic matter treatment was on average three times higher than that of chemical fertilizer treatment. The percent increases in $\mathrm{CO}_{2}$ evolution, and dehydrogenase activity, for composted soil in pea rotation at $120 \mathrm{Kg} \mathrm{N} /$ fed. were 34.1 and $185.87 \%$, respectively over the non-composted at $120 \mathrm{Kg} \mathrm{N} / \mathrm{fed}$. in potato rotation. The abovementioned results were in good accordance with the early explanation of Bolton et al. (1985) who illustrated that dehydrogenase is very useful for the estimation of soil microbial responses to organic manure because it is known to be associated primarily with microbial activities that are linked with the initial breakdown of organic material. Consistently, stronger dehydrogenase activity in soil treated with compost and FYM or compost-applied plots compared to soil treated with mineral fertilizer have been observed by many studies (Marinari et al., 2000; Wlodarczyk et al., 2002 and Khosro et al., 2011) which have been linked to higher organic matter content. The recorded data illustrated good co-relation between soil biological activity and organic matter content, as the lowest values were obtained from plots with no compost application. This result was in harmony with the total fungal and bacterial count as the organically treated plots recorded the maximum microbial population count (significant variation) compared with inorganically treated plots. In accordance Khosro et al. (2011) illustrated that the higher organic matter levels in the compost treatments may provide a more favorable situation for the accumulation of enzymes in the soil environment, as soil organic constituents are considered to be important to make up stable complexes with free enzymes. Tiemann and Grandy (2015) demonstrated also that microbial community functions, such as extracellular enzyme production and production of aggregate binding agents, have been linked to aggregate formation and soil organic matter increase. Many studies concluded that fungal-dominated communities have been associated with both qualitative and quantitative enhancement of soil 
Website: www.aun.edu.eg/faculty_agriculture/journals_issues_form.php E-mail:ajas@aun.edu.eg

organic matter accumulation with crop rotation (Six et al., 2006; Hungria et al., 2009 and McDaniel et al., 2014). Consistently, the current results showed maximum fungal population with significant improvement of SOC and total $\mathrm{N}$ in the organically treated plots. The results were in agreement with that reported by Nak- hro and Dkhar (2010) who illustrated that a significant variation in fungal population was found between organic and inorganic treated plots, they suggested that the application of organic fertilizers increased the organic carbon content of the soil and thereby increasing the microbial counts of the soil.

Table 7. Effect of compost manuring and $\mathrm{N}$-fertilization on chemical and biological characteristics of soil after maize harvest.

\begin{tabular}{|c|c|c|c|c|c|c|c|c|c|c|c|c|c|}
\hline Para & N/Fed & pH & $\begin{array}{c}\mathrm{EC} \\
\mathrm{dS} / \mathbf{m}^{2}\end{array}$ & $\begin{array}{c}\text { Organic } \\
\text { carbon } \\
(\%)\end{array}$ & $\begin{array}{c}\text { Total } \\
\text { nitrogen } \\
\text { (ppm) }\end{array}$ & $\begin{array}{c}\text { Total } \\
\text { soluble N } \\
(\text { ppm) }\end{array}$ & $\begin{array}{l}\text { Avail- } \\
\text { able P } \\
(\mathbf{p p m})\end{array}$ & $\begin{array}{l}\text { Avail- } \\
\text { able K } \\
\text { (ppm) }\end{array}$ & $\begin{array}{c}* \mathrm{CO} 2 \\
\text { evolu- } \\
\text { tion }\end{array}$ & $\begin{array}{c}* * \text { Dehydr- - } \\
\text { ogenase } \\
\text { activity }\end{array}$ & $\begin{array}{l}\text { Total count } \\
\text { of bacteria } \\
\text { (LogNo.) }\end{array}$ & $\begin{array}{c}\text { Total } \\
\text { count of } \\
\text { fungi } \\
(\operatorname{LogNo}) \\
\end{array}$ & $\begin{array}{c}\text { Total } \\
\text { count of } \\
\text { action. } \\
(\log \text { No. }) \\
\end{array}$ \\
\hline \multicolumn{14}{|c|}{ After Pea } \\
\hline 30 & \multirow{4}{*}{ 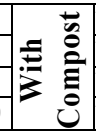 } & \multirow{4}{*}{\multicolumn{2}{|c|}{\begin{tabular}{|l|l|}
7.29 & 0.23 \\
7.30 & 0.24 \\
7.31 & 0.24 \\
7.31 & 0.25 \\
\end{tabular}}} & 0.36 & 293.30 & 50.93 & 12.23 & 113.80 & 8.60 & 82.40 & 5.92 & 3.63 & 4.70 \\
\hline 60 & & & & 0.38 & 297.30 & 52.40 & 12.40 & 115.50 & 9.56 & 94.83 & 5.93 & 3.69 & 4.70 \\
\hline 90 & & & & 0.46 & 304.00 & 53.60 & 12.80 & 117.70 & 10.90 & 99.67 & 5.93 & 3.79 & 4.71 \\
\hline 120 & & & & 0.55 & 513.30 & 55.10 & 12.90 & 121.40 & \begin{tabular}{|l|}
12.87 \\
\end{tabular} & 125.50 & 6.00 & 3.86 & 4.74 \\
\hline 30 & \multirow{4}{*}{ 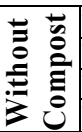 } & \multirow{4}{*}{\begin{tabular}{|l|}
7.75 \\
7.81 \\
7.58 \\
7.72 \\
\end{tabular}} & 0.21 & 0.28 & 260.00 & 48.9 & 8.80 & $105.3 \mathrm{O}$ & 7.56 & 40.20 & 5.46 & 3.56 & 4.62 \\
\hline 60 & & & 0.22 & 0.34 & 273.30 & 51.0 & 9.20 & 106.90 & 7.76 & 42.67 & 5.53 & 3.59 & 4.63 \\
\hline 90 & & & 0.23 & 0.37 & 283.00 & 52.5 & 9.26 & 107.20 & 8.46 & 43.93 & 5.49 & 3.63 & 4.66 \\
\hline 120 & & & 0.21 & 0.40 & 293.40 & 53.9 & 9.70 & 108.10 & 9.60 & 44.80 & 5.53 & 3.65 & 4.66 \\
\hline \multicolumn{14}{|c|}{ After Potato } \\
\hline 30 & \multirow{4}{*}{ 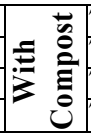 } & 7.33 & 0.20 & 0.34 & 256.00 & 46.73 & \begin{tabular}{l|l|}
11.20 & 1 \\
\end{tabular} & $114.2 \mathrm{~N}$ & 7.16 & 81.27 & 5.85 & 3.52 & 4.55 \\
\hline 60 & & 7.42 & 0.22 & 0.36 & 270.70 & 48.30 & 11.30 & 115.90 & 8.21 & 89.30 & $5.89-$ & 3.55 & 4.59 \\
\hline 90 & & 7.40 & 0.22 & 0.38 & 290.00 & 49.00 & 11.70 & 117.30 & \multirow{2}{*}{\begin{tabular}{|c|}
9.53 \\
10.50 \\
\end{tabular}} & \multirow{2}{*}{$\frac{90.23}{101.40}$} & \multirow{2}{*}{$\frac{5.98}{5.99}$} & 3.57 & 4.40 \\
\hline $\mathbf{1 2 0}$ & & 7.41 & 0.21 & 0.42 & 303.00 & 51.20 & 11.80 & 119.40 & & & & 3.40 & 4.62 \\
\hline 30 & & 7.19 & 0.23 & 0.26 & 240.40 & 35.50 & 8.10 & 99.5 & 6.80 & 36.27 & 5.30 & 3.51 & 4.44 \\
\hline 60 & & 7.83 & 0.23 & 0.31 & 252.20 & 38.80 & 8.30 & 100.1 & 7.46 & 41.73 & 5.39 & 3.53 & 4.46 \\
\hline 90 & 至 & 7.81 & 0.23 & 0.36 & 263.30 & 40.50 & 8.50 & 101.3 & 8.53 & 42.77 & 5.49 & 3.54 & 4.48 \\
\hline 120 & $\dot{0}$ & 7.56 & 0.22 & 0.36 & 268.70 & 45.60 & 8.40 & 102.2 & 9.33 & 43.90 & 5.55 & 3.55 & 4.52 \\
\hline L.S. & D.0.05 & N.S. & N.S. & 0.05 & 0.94 & 6.39 & 1.51 & 25.21 & 0.44 & 2.41 & 0.27 & 0.23 & 0.14 \\
\hline
\end{tabular}

NS=Not significant

Table 8. Some chemical and biological characteristics of soil before cultivation and after pea and potato harvest

\begin{tabular}{|c|c|c|c|c|}
\hline \begin{tabular}{|l} 
Parameters \\
Poil
\end{tabular} & $\begin{array}{l}\text { Control } \\
\text { (soil before } \\
\text { cultivation) }\end{array}$ & $\begin{array}{c}\text { Soil after } \\
\text { pea harvest }\end{array}$ & $\begin{array}{c}\text { Soil after potato } \\
\text { harvest }\end{array}$ & L.S.D.0.05 \\
\hline \multicolumn{5}{|l|}{ Chemical Feature } \\
\hline pH & $7.70 \pm 0.320$ & $7.40 \pm 0.210$ & $7.50 \pm 0.245$ & 0.24 \\
\hline$E C\left(d S / m^{2}\right)$ & $0.22 \pm 0.014$ & $0.23 \pm 0.045$ & $0.22 \pm 0.045$ & 0.06 \\
\hline Organic carbon (\%) & $0.21 \pm 0.011$ & $0.38 \pm 0.108$ & $0.26 \pm 0.061$ & 0.06 \\
\hline Total -N (ppm) & $233.3 \pm 12.350$ & $800.0 \pm 42.560$ & $666.7 \pm 35.480$ & 3.49 \\
\hline Total soluble-N ppm & $28.56 \pm 1.540$ & $58.85 \pm 2.452$ & $40.39 \pm 2.346$ & 0.09 \\
\hline Available phosphorus (ppm) & $9.82 \pm 0.340$ & $16.00 \pm 1.330$ & $11.3 \pm 0.250$ & 1.20 \\
\hline Available potassium (ppm) & $94.00 \pm 2.372$ & $115.00 \pm 3.45$ & $101.00 \pm 5.620$ & 3.33 \\
\hline \multicolumn{5}{|l|}{ Biological Feature } \\
\hline Dehydrogenase activity $(\mu \mathrm{g}$ TPF $/ 100 \mathrm{~g}$ dry soil/24h) & $35.33 \pm 1.850$ & $91.46 \pm 3.280$ & $85.73 \pm 3.452$ & 12.18 \\
\hline $\mathrm{CO}_{2}$ evolution rate $\left(\mathrm{mg} \mathrm{CO}_{2} / 100 \mathrm{~g}\right.$ soil $\left./ 24 \mathrm{~h}\right)$ & $4.82 \pm 0.242$ & $8.01 \pm 0.322$ & $7.87 \pm 0.220$ & 0.06 \\
\hline total bacteria log No. & $5.40 \pm 0.324$ & $6.10 \pm 0.178$ & $5.56 \pm 0.174$ & 0.46 \\
\hline Total fungi log No. & $3.21 \pm 0.110$ & $3.92 \pm 0.0682$ & $3.30 \pm 0.0624$ & 0.06 \\
\hline Total actinomycetes $\log$ No. & $4.20 \pm 0.242$ & $4.80 \pm 0.0845$ & $4.53 \pm 0.172$ & $\mathbf{0 . 1 3}$ \\
\hline
\end{tabular}




\section{Conclusion}

Crop rotation with legumes can be considered one of the most excellent alternatives for plant nutrient management by improving soil chemical and biological properties. Incorporation of grain legumes offer an effective $\mathrm{N}$ benefit to succeeding crops which efficiently reduce the Nfertilizer consumption and provide an economic benefit for yield production and farmers. In general, the coapplication of inorganic and organic manure through a crop rotation system including legumes, in newly reclaimed sandy soils, believed to be a good way for increasing yield and yield components of maize. The natural plant protection by crop rotation is another point should be taken in consideration.

\section{References}

Abdel-Wahab, A.F.M. (2008). Evaluation of enriched compost and its role in synergy with rhizobacteria and $\mathrm{N}$-fertilization for improving maize productivity in sandy soil. Arab Univ. J. Agric. Sci., Ain Shams Univ., Cairo. 16, 319-334.

Abdel-Wahab, A.F.M., Biomy, A.M., Abou-Zeid, M.Y. and El-Nagar, A.M.A. (2002). Influence of sewage sludge and bacterial inoculation on corn plants cultivated in newly reclaimed soil. J. Agric. Sci. Mansoura Univ., 27: 5835 - 5850.

Abedi, T., Alemzadeh, A. and Kazemeini, S.A. (2010). Effect of organic and inorganic fertilizers on grain yield and protein banding pattern of wheat. Australian J. of Crop Sci., 4: 384-389.

Alef, K. (1995). Enrichment, isolation and counting of soil microorganisms. In: Methods in Applied Soil Microbiology and Biochemistry,
Kassem, A. \& N. Paolo (Eds.). Academic Press, London, pp. 123191. https://doi.org/10.1016/b978012513840-6/50019-7.

Allen, O.N. (1957). Experiments in soil bacteriology. ed., Burgess Pub. Co., Minneapolis, pp. 1171.

Amanullah Khan, Jr., Almas, L.K., AlNoaim, M.I. (2015a). Nitrogen rates and sources affect yield and profitability of maize in Pakistan. Peshawar: Crop, Forage \& Turfgrass Management 1(1). https://doi.org/10.2134/cftm2014. 0021.

Amanullah, Asif, M., Almas, L.K., Amanullah, J., Shah, Z., Rahman, H.U. and Khalil, S.K. (2012). Agronomic efficiency and profitability of P-fertilizers applied at different planting densities of maize in northwest Pakistan. J. Plant Nutr. 35(3): 331-341. https://doi.org/10.1080/01904167. 2012.639916.

Amanullah, Imran Khan, Jan, A., Jan, M.T., Khalil, S.K., Shah, Z. and Afzal, M. (2015b). Compost and nitrogen management influence productivity of spring maize (Zea mays L.) under deep and conventional tillage systems in semi-arid regions. Commun. Soil Sci. Plant Analysis 46 (12): 1566-1578. https://doi.org/10.1080/00103624. 2015.1043462.

Amanullah, J., Asif, I., Ashraf, A., Shah, F., and Brajendra, P. (2016). Nitrogen source and rate management improve maize productivity of smallholders under semiarid climates. Front Plant Sci. 7: 1773. https://doi.org/10.3389/fpls. 201 6.01773 .

Arnon, D.I. (1949). Copper enzymes in isolated chloroplasts. Polyphenoloxidase in Beta Vulgaris. 
Plant Physiology, 24: 1-15. https://doi.org/10.1104/pp.24.1.1

Ashworth, A.J., Allen, F.L., Saxton, A.M. and Tyler, D.D. (2016). Longterm corn yield impacted by cropping rotations and bio-covers under no-tillage. Agron. J. 108 (4): $1495-1502$. https://doi.org/10.2134/agronj2015 .0453 .

Atlas, R.M. (2004). Handbook of Microbiological Media. $3^{\text {rd }}$ ed., CRC Press LLC, Boca Raton, Florida, USA, pp. 2056 - 2080.

Bakhtiar, S., Estiveira, R.J. and HattiKaul, R. (2005). Substrate specificity of alkaline proteases from alkalophilic feather-degrading Nesterenkonia sp AL20. Enzyme Microb Technol, 37(5): 534-540. https://doi.org/10.1016/j.enzmicte c.2005.04.003.

Black, C.A., Evans, D.D., Ensminger, L.E., White, J.L., Clark, F.E. and Dinauer, R.C.(1965). Methods of soil analysis. part 2, chemical and microbiological properties. ed., Amer. Soc. Agron. Inc., Pub. Madison, Wisconsin, USA. https://doi.org/10.2134/agronmon ogr9.2.2ed.

Bokhtiar, S.M. and Sakurai, K. (2005). Integrated use of organic manure and chemical fertilizer on growth, yield, and quality of sugarcane in high ganges river floodplain soils of Bangladesh. Communications in Soil Science and Plant Analysis, 36 (13-14): 1823-1837. https://doi.org/10.1081/css200062460

Bolton, H., Elliott, L.F., Papendick, R.I. and Bezdicek, D.F. (1985). Soil microbial biomass and selected soil enzyme activities: effect of fertilization and cropping practices. Soil Biol Biochem 17(3): 297-302. https://doi.org/10.1016/0038-0717 (85)90064-1

Brady, N.C. and Weil, R.R. (2005). The nature and properties of soil. 13th edition, New Jersey: Prentice-Hall, Inc. 887, 902, 905 and 960p.

Casida, L.E. (1977). Microbial metabolic activity in soil as measured by dehydrogenase determinations. Applied and environmental microbiol., 34: 630-636.

Cazzato, E., Tufarelli, V., Ceci, E., Stellacci, A. M., and Laudadio, V. (2012). Quality, yield and nitrogen fixation of faba bean seeds as affected by sulphur fertilization. Acta Agriculturae Scandinavica B: Soil Plant Sci., 62(8): 732-738. https://doi.org/10.1080/09064710. 2012.698642.

Chalk, P.M., Smith, C.J., Hamilton, S.D. and Hopmans, P. (1993). Characterization of the $\mathrm{N}$ benefit of a grain legume (Lupinus angustifolius L.) to a cereal (Hordeum vulgare L.) by an in situ ${ }^{15} \mathrm{~N}$ isotope dilution technique. Biol. Fertil. Soils 15(1): 39-44. https://doi.org/10.1007/bf0033628 6.

Chen, L. (1993). Crop sequences for sustaining soil resources in China. In International Crop Science-I. Crop Sc. Society of America, USA 895 p. https://doi.org/10.2135/1993.inte rnationalcropscience.c9.

Das Ipsita and Singh, A. P. (2014). Effect of organic manures and PGPR on nutrient content and uptake of mungbean. Unique Research Journal of Chemistry (URJC) 2 (2): 912.

Dick, R.P. (1992). A review: long-term effects of agricultural systems on soil biochemical and microbial parameters. Agriculture, Ecosystems 
\& Environment, 40: (1-4) 25-36. https://doi.org/10.1016/0167-8809 (92)90081-1.

Doran, J.W., Sarrantonio, M. and Liebig, M. (1996). Soil health and sustainability. In: Sparks, D.L. (Ed.), Advances in Agronomy, Vol. 56. Academic Press, San Diego, pp. 154. https://doi.org/10.1016/s00652113(08)60178-9.

El Sayed, S. Y. (2007). Utilization of some biological resources in biocontrol and promotion of some legume plants growth. M.Sc. Thesis, Women's college for Arts, Science and Education. Ain Shams Univ., Egypt, pp. 66-87.

Erocli, L., Lulli, L., Mariotti, M., Masoni, A. and Arduini, I. (2008). Post-anthesis dry matter and nitrogen dynamics in durum wheat as affected by nitrogen supply and soil water availability. Euro J. Agron. 28(2):138-147. https://doi.org/10.1016/j.eja. 2007.06.002

Fischer, R.A., Santiveri, F. and Vidal, I.R. (2002). Crop rotation, tillage and crop residue management for wheat and maize in the sub-humid tropical highlands: I. Wheat and legume performance. Field Crops Res. 79(2):107-122. https://doi.org/ 10.1016/s03784290(02)00157-0

Foley, B.J. and Cooperband L.R. (2002). Paper mill residuals and compost effects on soil carbon and physical properties. J. Environ. Qual., 31(6): 2086-2095. https://doi.org/ 10.2134/jeq2002. 2086.

Gan, Y., Hamel, C., O’Donovan, J.T., Cutforth, H., Zentner, R.P., Campbell, C.A., Niu Y. and Poppy, L. (2015). Diversifying crop rotations with pulses enhances system productivity. Nature Scientific Re- ports 5: 14625. https://doi.org/ 10.1038/ srep14625.

Grimont, P.A.D. and Grimont, F. (1984). Genus VIII. Serratia. In: Bergey's Manual of Systematic Bacteriology, Kreig, N.R. \& J.G. Baltimore (Eds.). Lippincott Williams \& Wilkins, Baltimore, USA, pp. 477484.

Guo, C., Li, P., Lu, J., Ren, T., Cong, R. and Li, X. (2016). Application of controlled release urea in rice: reducing environmental risk while increasing grain yield and improving nitrogen use efficiency. Commun. Soil Sci. Plant Anal. 47:(9) 1176-1183. https://doi.org/10.1080/00103624. 2016.1166235

Hardy, R.W.F., Burns, R.C. and Holsten, R.D. (1973). Applications of the acetylene-ethylene assay for measurement of nitrogen fixation. Soil Biology and Biochemistry, 5(1): 47-81. https://doi.org/10.1016/ 0038-0717(73)90093-x.

Herridge, D.F., Marcellos, H., Felton, W.L., Turner, G.L. and Peoples, M.B. (1995). Chickpea increases soil-N fertility in cereal systems through nitrate sparing and N2 fixation. Soil Biology and Biochemistry, 27(4-5): 545-551. https://doi.org/10.1016/0038-0717 (95)98630-7.

Hiel, M.P., Chélin, M., Parvin, N., Barbieux, S., Degrune, F., Lemtiri, A, Colinet, G., Degré, A., Bodson, B. and Garré, S. (2016). Crop residue management in arable cropping systems under a temperate climate. Part 2: Soil physical properties and crop production. A review. Biotechnol. Agron. Soc. Environ. 20(1): 245-256 https:// doi.org/10.1890/04-0922

Hungria, M., Franchini, J.C., BrandaoJunior, O., Kaschuk, G. and Souza, 
R.A. (2009). Soil microbial activity and crop sustainability in a longterm experiment with three soil-tillage and two crop-rotation systems. Appl. Soil Ecol., 42(3): 288-296.

https://doi.org/10.1016/j.apsoil.20 09.05.005.

Jackson, M.L. (1973). "Soil Chemical Analysis" Prentice- Hall India Private Limitrd, New Delhi. 13-149.

Jastrow, J.D., Amonette, J.E. and Bailey, V.L. (2007). Mechanisms controlling soil carbon turnover and their potential application for enhancing carbon sequestration. Clim. Climatic Change 80 (1-2): 5-23. https://doi.org/10.1007/s10584006-9178-3.

Jayathilake, P.K.S., Reddy, I.P, Srihar, I.D. and Reddy, K.R. (2006). productivity and soil fertility status as influenced by integrated use of $n$ fixing biofertilizers, organic manures and inorganic fertilizers in onion. J. of Agricultural Sciences, 2(1): $\quad 46-58$. https://doi.org/10.4038/jas.v2i1.81 12.

Kang, G.S., Beri, V., Rupela, O.P. and Sidhu, B.S. (2005). A new index to assess soil quality and sustainability of wheat cropping systems. Biol. Fertil. Soils, 41(6): 389-398. https://doi.org/10.1007/s00374005-0857-4.

Khosro, M., Amir G., Majid, A., Gholamreza, H., Behzad, S. and Yousef, S.(2011). Effect of different methods of crop rotation and fertilization on canola traits and soil microbial activity. Australian J. of Crop Sc. 5(10):1261-1268.

Kirkegaard, J., Christen, O., Krupinsky, J. and Layzell, D. (2008). Break crop benefits in temperate wheat production. Field Crops Research, 107(3):

185-195 https://doi.org/10.1016/j.fcr.2008.0 2. 010 .

Kouyaté, Z., Franzluebbers, K., Juo, A.S.R., and Hossner, L. (2000). Tillage, crop residue, legume rotation, and green manure effects on sorghum and millet yields in the semiarid tropics of Mali. Plant and Soil 225(1): 141-151.

Lupwayi, Z.N., Kennedy, C.A. and Rowland, M.C. (2011). Grain legume impacts on soil biological processes in sub-Saharan Africa. African J. of Plant Sc. 5: 1-7.

Malakooti, M.J., Gheybi, N. (2003). Principals of feeding corn. Fertilizer optimization step towards selfsufficiency in maize production in the country (Iran). (Proceedings). Sena Publications, Tehran, Iran. pp.346. (In Farsi).

Marinari, S., Masciandaro, G., Ceccanti, B. and Grego, S. (2000). Influence of organic and mineral fertilizers on soil biological and physical properties. Biores Technol 72(1): 9-17. https://doi.org/10.1016/s09608524(99)00094-2.

Martin, J.P. (1950). Use of Acid, Rose Bengal, and Streptomycin in the Plate Method for Estimating Soil Fungi. Soil Science, 69, 215-232.

McDaniel, M.D., Tiemann, L.K., and Grandy, A.S. (2014). Does agricultural crop diversity enhance soil microbial biomass and organic matter dynamics? A meta- analysis. Ecol. Appl. 24(3):560-570. https://doi.org/10.1890/130616.1.

Meng, P.P., Liu, X., Qiu, H.Z., Zhang, W.R., Zhang, C.H., Wang, D., Zhang, J.L. and Shen, Q.R. (2012). Fungal population structure and its biological effect in rhizosphere soil of continuously 
cropped potato. Chin. J. Appl. Ecol. 23(11): 3079-3086.

Muhammad, A., Mohammad, T. J., Mohammad, J. K., Muhammad S., Iqbal M., Z., Habib A., Shahenshah and Muhammad, Z.K. (2011). Effect of cropping system and residue management on maize. Pak. J. Bot., 43(2): 915-920.

Nakhro, N. and Dkhar, M. S. (2010). Impact of organic and inorganic fertilizers on microbial population and biomass carbon in paddy field soil. J. of Agronomy 9 (3):102110.

https://doi.org/10.3923/ja.2010.10 2.110 .

Page, A.L., Miller, R.H. and Keeney, D.R. (1982). Methods of soil analysis. ii., chemical and microbiological properties. ed., Madison, Wisconsim, USA. https://doi.org/10.1002/jpln.19851 480319.

Pokhrel, S. and Pokhrel, S. (2013). Legumes crop rotation can improve food and nutrition security in Nepal. Agronomy J. of Nepal (Agron JN) 3: 123-127. https://doi.org/ 10.3126/ajn.v3i0.9014.

Preissel, S., Reckling, M., Schläfke, N. and Zander, P. (2015). Magnitude and farm-economic value of grain legume pre-crop benefits in Europe: a review. Field Crop Res. 175: 64-79. https://doi.org/10.1016/j.fcr. 2015.01.012.

Rehman, H.U., Ali, A., Waseem, M., Tanveer, A.S., Tahir, M., Nadeem, M.A. and Zamir, M.S.I. (2010). Impact of nitrogen application on growth and yield of maize (Zea mays L.) grown alone and in combination with cowpea (Vigna unguiculata L.). American-Eurasian J. Agric. \& Environ. Sci., 1: 43-47.
Rutkowska, A. and Pikula D. (2013). Effect of Crop Rotation and Nitrogen Fertilization on the Quality and Quantity of Soil Organic Matter. [In:] Soil Processes and Current Trends in Quality Assessment. (M.C. Hernandez Soriano, Editors) In Tech, Rijeka, Croatia: 249-267. https://doi.org/10.5772/53229.

Sarwar, G., Hussain, N., Schmeisky, H. and Muhammad, S. (2008a). Efficiency of various organic residues for enhancing rice-wheat production under normal soil conditions. Pakistan J. Botany. 40: 2107-2113.

Sarwar, G., Hussain, N., Schmeisky, H., Muhammad, S., Ibrahim, M. and Safdar, E. (2008b). Improvement of soil physical and chemical properties with compost application in rice-wheat cropping system. Pakistan J. of Botany, 1: 275-282.

Senigagliesi, C., Ferrari, M. (1993). Soil and crop responses to alternative tillage practices. (Eds.), International Crop Science. I. Crop Science Society of America, USA Madison, pp. 27-35. https://doi.org/10.2135/1993.inter nationalcropscience.c6

Sharifi, R.S. and Taghizadeh, R. (2009). Response of maize (Zea mays L.) cultivars to different levels of nitrogen fertilizer. J. Food, Agric. and Environ. 7 (3 - 4): 518- 521.

Six, J., Frey, S.D., Thiet, R.K. and Batten, K.M. (2006). Bacterial and fungal contributions to carbon sequestration in agroecosystems. Soil Sci. Soc. Am. J.70 (2): 555-569. https://doi.org/10.2136/sssaj200 4.0347.

Smiley, R.W., Ingham, R.E., Uddin, W. and Cook, G.H. (1994). Crop sequences for managing cereal cyst nematode and fungal pathogens of winter wheat. Plant Dis., 78(12): 1142-1149. 
https://doi.org/10.1094/pd-781 142.

Snedecor, G.W. and Cochran, W.G. (1980). "Statistical Methods" 7th Ed., ed., Iowa State Univ. Press, Amr, USA, pp.255-269.

Stanger, T. and Lauer, J. (2008). Corn Grain Yield Response to Crop Rotation and Nitrogen over 35 Years. Agronomy J. 100(3): 643-650. https://doi.org/10.2134/ agronj200 7.0280 .

Tiemann, L.K. and Grandy, A.S. (2015). Mechanisms of soil carbon accrual and storage in bioenergy cropping systems. Glob. Change Biol. Bioenergy, 7 (2): 161-174. https://doi.org/ 10.1111/gcbb.1212 6.

Tilman, D., Reich, P.B. and Knops, J.M. (2006). Biodiversity and ecosystem stability in a decade-long grassland experiment. Nature, 441(7093): $\quad$ 629-632. https://doi.org/10.1038/nature047 42.

Vincent, J.M. (1970). A Manual for the Practical Study of Root Nodule Bacteria. Oxford: Blackwell Scientific. P. 164.

Wilde, S.A. and Voigt, G.K. (1949). Absorption-transpiration quotient of nursery stock. J. of Forestry, 47: 643-645.
Wlodarczyk, T., Stepniewski, W. and Brzezinska, M. (2002). Dehydrogenase activity, redox potential, and emissions of carbon dioxide and nitrous oxide from Cambisols under flooding conditions. Biol. Fert. Soils 36(3): 200-206. https://doi.org/10.1007/s00374-0 0 2-0513-1

Xing, H., Liu, D. L., Li, G., Wang, B. , Anwar, M. R., Crean, J., LinesKelly, R. and Yu, Q. (2017). Incorporating grain legumes in cereal-based cropping systems to improve profitability in southern New South Wales, Australia Agricultural Systems 154:112-123. https://doi.org/10.1016/j.agsy.201 7.03.010.

Yaduvanshi, N.P.S. (2001). Effect of five years of rice-wheat cropping and NPK fertilizer use with and without organic and green manures on soil properties and crop yields in a reclaimed sodic soil. J. Indian Soc. Soil Sci., 49: 714-719.

Yaseen, M., Arshad, M. and Khalid, A. (2006). Effect of acetylene and ethylene gases released from encapsulated calcium carbide on growth and yield of wheat and cotton. Pedobiologia., 50(5): 405-411. https://doi.org/10.1016/j.pedobi.20 06.08.002. 
تأثير التعاقب المحصولي و الكمبوست والبقايا النباتيه علي إنتاج الذره الثاميه وخصوية

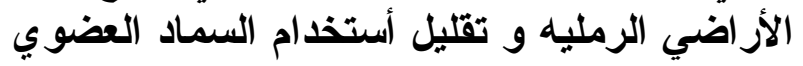

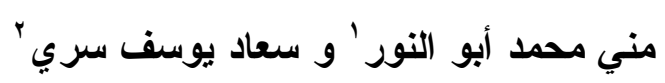

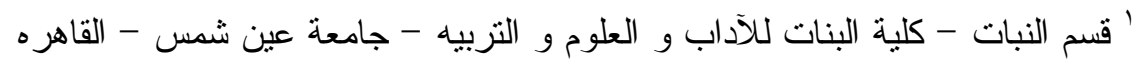

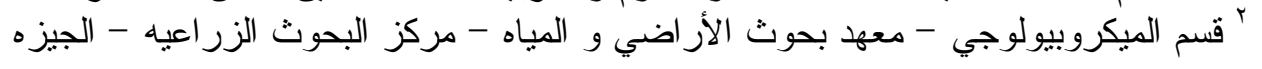

الملخص

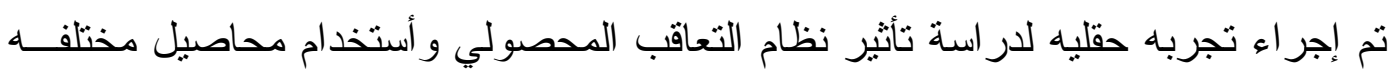

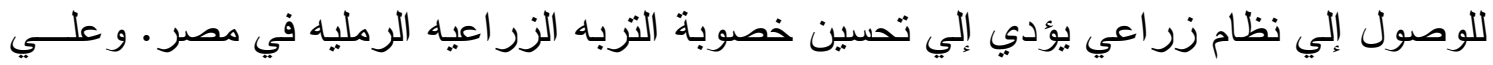

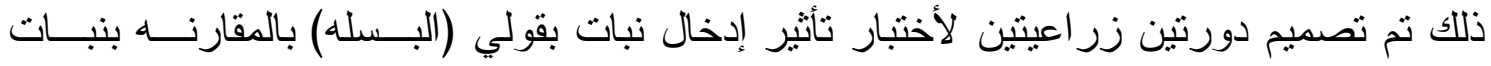

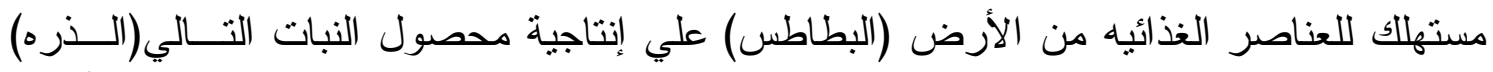

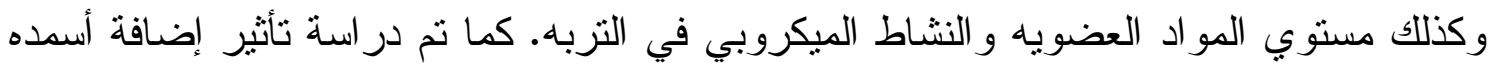

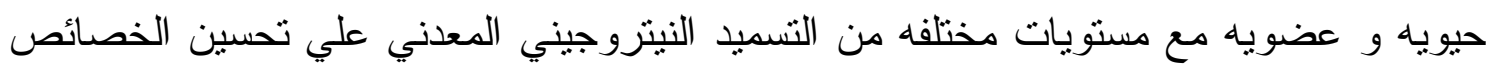

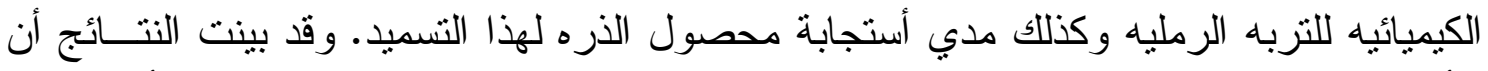

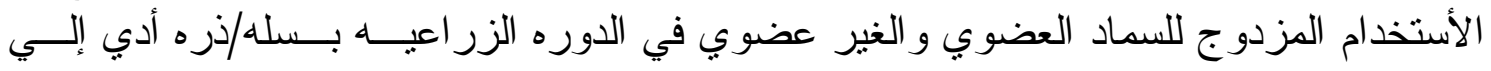

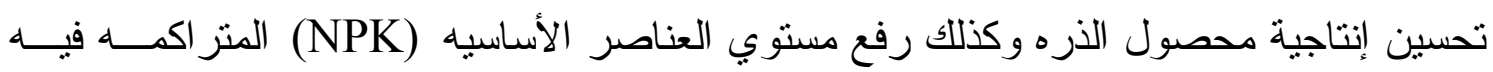

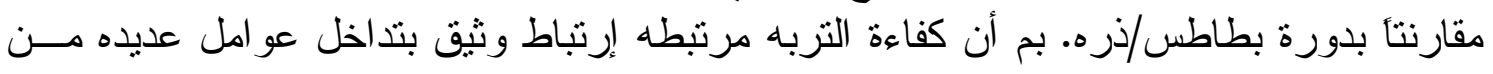

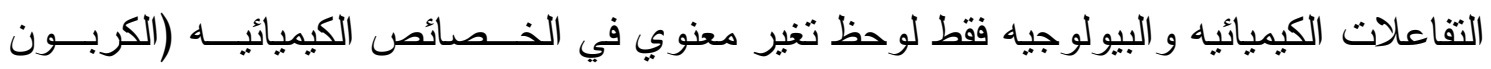

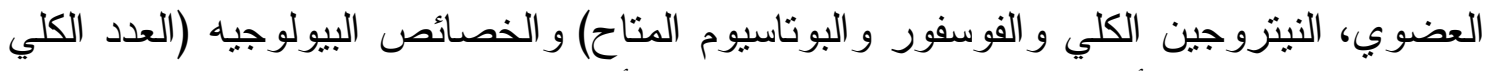

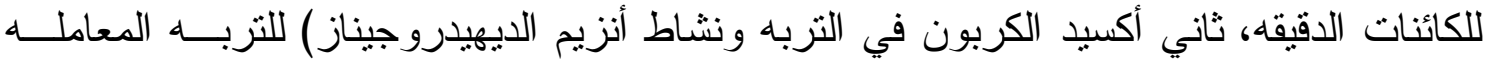

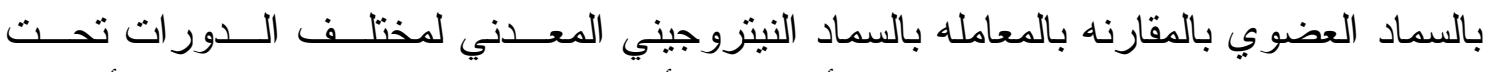

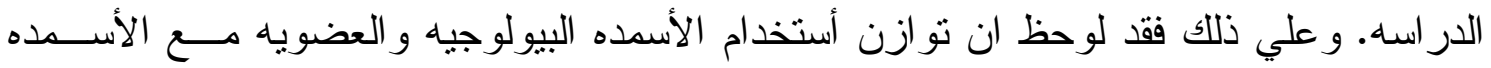

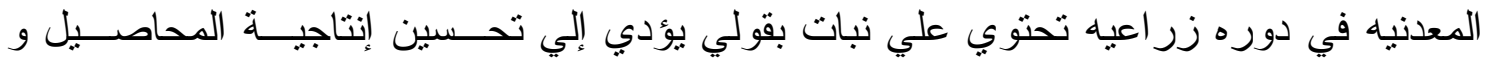

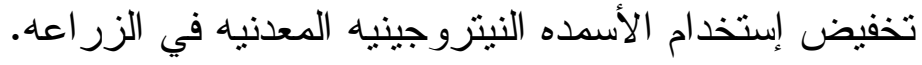

